University of Nebraska - Lincoln

DigitalCommons@University of Nebraska - Lincoln

Publications from USDA-ARS / UNL Faculty

U.S. Department of Agriculture: Agricultural

Research Service, Lincoln, Nebraska

2011

Nutrient Cycling in Soils: Sulfur

John L. Kovar

USDA-ARS, john.kovar@ars.usda.gov

Cynthia A. Grant

Agriculture and Agri-Food Canada

Follow this and additional works at: https://digitalcommons.unl.edu/usdaarsfacpub

Kovar, John L. and Grant, Cynthia A., "Nutrient Cycling in Soils: Sulfur" (2011). Publications from USDAARS / UNL Faculty. 1383.

https://digitalcommons.unl.edu/usdaarsfacpub/1383

This Article is brought to you for free and open access by the U.S. Department of Agriculture: Agricultural Research Service, Lincoln, Nebraska at DigitalCommons@University of Nebraska - Lincoln. It has been accepted for inclusion in Publications from USDA-ARS / UNL Faculty by an authorized administrator of DigitalCommons@University of Nebraska - Lincoln. 


\section{Nutrient Cycling in Soils: Sulfur}

John L. Kovar and Cynthia A. Grant

Sulfur is an essential element required for normal plant growth, a fact that has been recognized since 1860 (Alway, 1940). It is considered a secondary macronutrient, following the primary macronutrients nitrogen, phosphorus, and potassium, but is needed by plants at levels comparable to P. Sulfur deficiency will impair basic plant metabolic functions, thus reducing both crop yield and quality. Deficiencies and responses to $S$ amendments have been reported in crops worldwide (Tisdale et al., 1986; McGrath and Zhao, 1995; Scherer, 2001), and are becoming more common (Haneklaus et al., 2008). The likelihood of a response is determined by the balance between sulfur supply and crop demand. The main reasons for recent increases in documented $\mathrm{S}$ deficiencies include the reduction of $\mathrm{SO}_{2}$ emissions from various industrial sources, mainly coal-fired power plants, an increase in the use of high-analysis fertilizers with little $\mathrm{S}$, decreased use of S-containing pesticides, greater $\mathrm{S}$ removals with ever-increasing crop yields, and continued losses through leaching and erosion of topsoil. As pointed out by Haneklaus et al. (2008), in only a few years, the reputation of $S$ has changed from that of an undesirable pollutant to a limiting factor in crop production.

In this chapter, we provide current information on the demand for $S$ in various cropping systems, what we know about the soil supply of $S$, the best ways of assessing $S$ status and managing $S$ inputs, and how all of this information can be put together to optimize crop production. In each section, references will provide the reader with an opportunity to explore the topic in greater detail than can be given in these few pages.

\section{Crop Demand for Sulfur}

Substantial increases in the yields of major cereal and oilseed crops during the last four decades have greatly increased crop demand for S. With world population expected to rise to 9.2 billion by 2050 , crop production and consequently $S$ supply must increase as well.

The requirement for $\mathrm{S}$ or any other nutrient by a crop can be defined as the total amount of nutrient in the crop $\left(\mathrm{kg} \mathrm{ha}^{-1}\right)$ or the concentration $\left(\mathrm{g} \mathrm{kg}^{-1}\right)$ of the nutrient in the whole plant or specific plant part that is associated with optimum growth. Data on crop S contents are useful in calculating $S$ removals from a field and for estimating $S$ fertilizer needs. Critical concentrations of $S$ in plant tissue are useful in diagnosing in-season $S$ deficiencies. Numerous references provide critical plant tissue $S$ concentrations for various crop species (Table 7l1) (Westerman, 1990; Bennett, 1993; Mills and Jones, 1996). Both public and commercial plant analysis laboratories

J.L. Kovar, USDA-ARS, National Laboratory for Agriculture and the Environment, 2110 University Boulevard, Ames, IA 50011-3120 (John.Kovar@ars.usda.gov); C.A. Grant, Agriculture and Agri-Food Canada, Brandon Research Centre, Brandon, Manitoba, Canada.

doi:10.2136/2011.soilmanagement.c7

Copyright @ 2011 . American Society of Agronomy and Soil Science Society of America, 5585 Guilford Road, Madison, WI 53711, USA. Soil Management: Building a Stable Base for Agriculture. Jerry L. Hatfield and Thomas J. Sauer (ed.) 
Table $7 \mid 1$. Critical sulfur concentrations in plant tissue of various crop species. Adapted from Mills and Jones (1996) and Dick et al. (2008).

\begin{tabular}{|c|c|c|c|c|c|c|}
\hline \multirow{2}{*}{ Crop } & \multirow{2}{*}{ Part sampled $\dagger$} & \multirow{2}{*}{ Time of sampling } & \multicolumn{4}{|c|}{ Critical concentration at various uptake levels } \\
\hline & & & Deficient & Low & Sufficient & High \\
\hline & & & & & 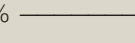 & 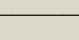 \\
\hline Alfalfa & top $15 \mathrm{~cm}$ & early bud & $<0.20$ & $0.20-0.25$ & $0.26-0.50$ & $>0.50$ \\
\hline Barley & whole top & heading & & & $0.15-0.40$ & \\
\hline Canola/rape & YMB & before flowering & & & $0.35-0.47$ & \\
\hline Cotton & YMB & early flowering & & & $0.20-0.25$ & \\
\hline Cowpea & YML & early bloom & & & $0.17-0.22$ & \\
\hline Maize & ear leaf & initial silk & $<0.10$ & $0.10-0.20$ & $0.21-0.50$ & $>0.50$ \\
\hline Oats & top leaves & boot stage & $<0.15$ & $0.15-0.20$ & $0.21-0.40$ & $>0.40$ \\
\hline Onion & whole top & half maturity & & & $0.50-1.0$ & \\
\hline Peanut & YML & pre-flowering & & & $0.20-0.35$ & \\
\hline Rice & whole top & max. tillering & & $0.10-0.20$ & $0.20-0.30$ & $>0.30$ \\
\hline Ryegrass & young herbage & active growth & & & $0.10-0.25$ & \\
\hline Soybean & first trifoliate & early flower & $<0.15$ & $0.15-0.20$ & $0.21-0.40$ & $>0.40$ \\
\hline Sugar cane & third leaf from tip & $\begin{array}{l}12-15 \text { wk. after } \\
\text { planting }\end{array}$ & & & $0.14-0.20$ & \\
\hline Sunflower & YML & mid-season & & & $0.30-0.55$ & \\
\hline White clover & young herbage & active growth & & & $0.18-0.30$ & \\
\hline Wheat & YEB/YMB & mid-late tillering & & & $0.15-0.40$ & \\
\hline
\end{tabular}

† YEB, youngest emerged leaf blade; YMB, youngest mature leaf blade; YML, youngest mature leaf.

often provide critical values online. Sulfur concentration in most crop plants ranges between 0.1 and $1.5 \% \mathrm{~S}$, although concentrations in excess of $3 \%$ have been reported for crops grown under saline conditions (Duke and Reisenauer, 1986). In general, S concentrations in grain are higher than in vegetative tissue.

Visual symptoms of $\mathrm{S}$ deficiency can be used as a diagnostic tool; however, symptoms will vary with crop species and the degree of deficiency (Duke and Reisenauer, 1986). Sulfur deficiency symptoms include reduced plant growth and chlorosis of the younger leaves, beginning with interveinal yellowing that gradually spreads over the entire leaf area. Unlike $\mathrm{N}$, which can be readily remobilized in the plant, $\mathrm{S}$ is somewhat immobile, so that deficiency symptoms tend to occur first in younger leaves. With severe deficiencies, leaf cupping and a more erect leaf structure is often observed. This characteristic is common with canola (Brassica napus L. and B. rapa L.) (Franzen and Grant, 2008). Under mild to moderate $S$ deficiency, however, visual symptoms may not always be a reliable indicator. Photos of S deficiency symptoms are available from many sources, including printed works (e.g., Bennett, 1993) and online sources (e.g., http://www.backto-basics.net/nds/index.htm [verified $4 \mathrm{Feb}$. 2011]). Applications of soluble sulfate fertilizer often can correct a deficiency and increase crop yield and quality in the same growing season.

\section{Responsive Crops}

The $S$ content of plants differs greatly among crop species, among cultivars within a species, and with developmental stage. Most species of the Cruciferae and Liliaceae families contain the largest amounts of S (Scherer, 2001). In general, the oilseed crops, such as oilseed rape (Brassica napus L.), canola, and sunflower (Helianthus annuus L.), and legumes, such as alfalfa (Medicago sativa L.) and soybean [Glycine max (L.) Merr.], have a much higher requirement for $S$ than the small grains and maize (Zea mays L.) (Duke and Reisenauer, 1986). Whole plant $\mathrm{S}$ content is often higher during vegetative 
growth stages than at maturity. Malhi and Gill (2002) found that the demand for S by canola was greatest during flowering and seed set. Gregory et al. (1979) recorded a $50 \%$ decrease in plant S content of wheat during the period from anthesis to maturity, and speculated that efflux from roots into soil was the most likely pathway of loss. Plants also release measurable amounts of $S$ into the atmosphere when $S$ concentrations in foliage are high due to exposure to sulfur dioxide or excessive S uptake from soil (Janzen and Ellert, 1998).

Crop removal of $S$ is a function of yield and $S$ concentration in the harvested biomass (grain or dry matter). Sulfur removals by various crops as a function of yield are given in Table $7 / 2$. Similar data are available from many sources (Spencer, 1975; Tabatabai, 1986; Jez, 2008). Currently, much of the $\mathrm{S}$ assimilated by the crop is retained in the system in plant residues returned to the soil. Intensification of cropping systems, however, has led to higher yields and accelerated crop S removal, which places greater demand on soil supply of $S$.

\section{Sulfur Acquisition and Uptake}

The majority of $S$ required by a plant is absorbed from soil solution by roots in the form of the divalent sulfate anion, $\mathrm{SO}_{4}{ }^{2-}$ (Barber, 1995). Similar to nitrate and phosphate, sulfate is taken up by specialized transporters in root cells and transported with the transpiration stream (Hawkesford and De Kok, 2006). Atmospheric $\mathrm{SO}_{2}$ can be phytotoxic at high concentrations, but can also be captured and metabolized as a S source for plants when the S supply to roots is limiting (Westerman et al., 2000; Stuiver and De Kok, 2001). Sulfur that is captured directly from the atmosphere is eventually deposited in the soil as plant residue (Dick et al., 2008).

Because sulfate is an integral part of several metabolic pathways, an insufficient supply negatively affects plant metabolism. Sulfate taken up by roots must be reduced to sulfide $\left(\mathrm{S}^{2-}\right)$, before it is further metabolized. Reduction of sulfate to sulfide and its subsequent incorporation into cysteine (sulfate assimilation) occurs in the chloroplasts of the shoot (Droux, 2004). Cysteine is the precursor of methionine and most other organic sulfur compounds in plants, including thiols (glutathione), sulfolipids, and secondary
Table 7|2. Sulfur removals of various crops at the given yield levels. Adapted from Dick et al. (2008).

\begin{tabular}{|c|c|c|c|}
\hline Crop & $\begin{array}{l}\text { Plant } \\
\text { component }\end{array}$ & Yield & S content \\
\hline & & $\mathrm{Mg} \mathrm{ha}^{-1}$ & $\mathrm{~kg} \mathrm{ha}^{-1}$ \\
\hline Alfalfa & biomass & 13 & 34 \\
\hline Canola/rapeseed & grain & 2.2 & 13 \\
\hline Cool-season grass & biomass & 9.0 & 18 \\
\hline Cotton & lint & 1.7 & 45 \\
\hline \multirow[t]{2}{*}{ Grain sorghum } & grain & 9.4 & 25 \\
\hline & residue & $-\dagger$ & 18 \\
\hline \multirow[t]{2}{*}{ Maize } & grain & 11.5 & 15 \\
\hline & stover & 6.9 & 10 \\
\hline Orange & fruit & 60 & 31 \\
\hline Peanut & tuber & 4.5 & 24 \\
\hline Potato & tuber & 56 & 25 \\
\hline Rice & grain & 7.8 & 13 \\
\hline \multirow[t]{2}{*}{ Soybean } & grain & 4.0 & 13 \\
\hline & residue & - & 15 \\
\hline Sugar Beet & tuber & 67 & 50 \\
\hline \multirow[t]{2}{*}{ Sunflower } & seed & 3.9 & 7 \\
\hline & residue & - & 11 \\
\hline Tomato & fruit & 67 & 46 \\
\hline \multirow[t]{2}{*}{ Wheat } & grain & 5.4 & 8 \\
\hline & straw & - & 17 \\
\hline
\end{tabular}

† Sulfur removals in stover, straw, and crop residues are estimates based on typical values of a harvest index (i.e., the ratio of harvested grain to total plant biomass). In most cases, the crop residues are not harvested and the $\mathrm{S}$ would not be removed from the field.

metabolites (alliins, glucosinolates, and phytochelatins). These compounds are important for the physiology of plants and for resistance to environmental stresses and pests (Duke and Reisenauer, 1986). In addition to sulfate, $\mathrm{S}$ is moved within the plant in the reduced form as glutathione (Hawkesford and De Kok, 2006). Cysteine and methionine play a crucial role in the structure and function of plant proteins. Sulfur is involved in basic plant functions, such as photosynthesis and carbon and nitrogen metabolism (Droux, 2004). At present, however, the complex interactions between the shoot and roots that regulate $S$ assimilation in relation to uptake and distribution are still poorly understood (Hawkesford and De Kok, 2006).

Sulfur compounds are important for crop quality. Haneklaus et al. (1992) found 
that insufficient $S$ diminished the baking quality of wheat (Triticum aestivum L.) well before crop productivity decreased. Zhao et al. (1999) reported that a grain N/S ratio of 16:1 in wheat was the lower limit for optimum dough and bread-making properties. The S-containing amino acids in soybean are of particular nutritional importance in animal diets (Krishnan, 2008). Sulfur compounds in onion (Allium cepa L.), garlic (Allium sativum L.), and other Allium species determine the flavor profile of these crops (Boyhan, 2008). Defects in potato (Solanum tuberosum L.) tubers often result when $S$ uptake is below optimum. Pavlista (2005) found that common scab and black scurf were reduced by early-season applications of elemental S, ammonium sulfate, or ammonium thiosulfate during a 6-yr study in the western United States. Haneklaus et al. (2008) concluded that a balanced nutrient supply, including $S$ fertilization, for agricultural crops is the best guarantee for producing healthy foods.

\section{Soil Supply of Sulfur}

A general understanding of the basic processes involved in the soil S cycle is necessary to ensure proper $S$ nutrition of crop plants. Total $S$ in soils varies widely and depends on organic matter content, soil parent material, and the amount of $S$ added via fertilizer amendments and atmospheric deposition (Scherer, 2009). Inorganic S is subject to adsorption, desorption, precipitation, and oxidation-reduction reactions, while organic $S$ is subject to mineralization and immobilization (Fig. 7/1). Because soil $\mathrm{S}$ is continuously cycled between inorganic and organic forms, these processes determine the short- and long-term ability of a soil to supply available $\mathrm{S}$. The soil $\mathrm{S}$ cycle has been reviewed extensively in the literature (Stevenson and Cole, 1999; Schoenau and Malhi, 2008; Scherer, 2009).

\section{Inorganic Sulfur}

As mentioned above, inorganic sulfate is the form of $\mathrm{S}$ absorbed by plant roots growing in soil. In general, less than $5 \%$ of total $\mathrm{S}$ in soil is the sulfate form. Sulfate can be present in soil solution, adsorbed on mineral surfaces, or coprecipitated with $\mathrm{Ca}$ and $\mathrm{Mg}$. In well-drained surface soils with neutral to alkaline $\mathrm{pH}$, sulfate exists mainly in the form of soluble salts of $\mathrm{Ca}, \mathrm{Mg}$, and $\mathrm{Na}$. Solution sulfate concentrations of 3 to $5 \mathrm{mg}$ $\mathrm{L}^{-1}$ are considered adequate for the growth of most crops, but concentrations change continuously depending on the balance

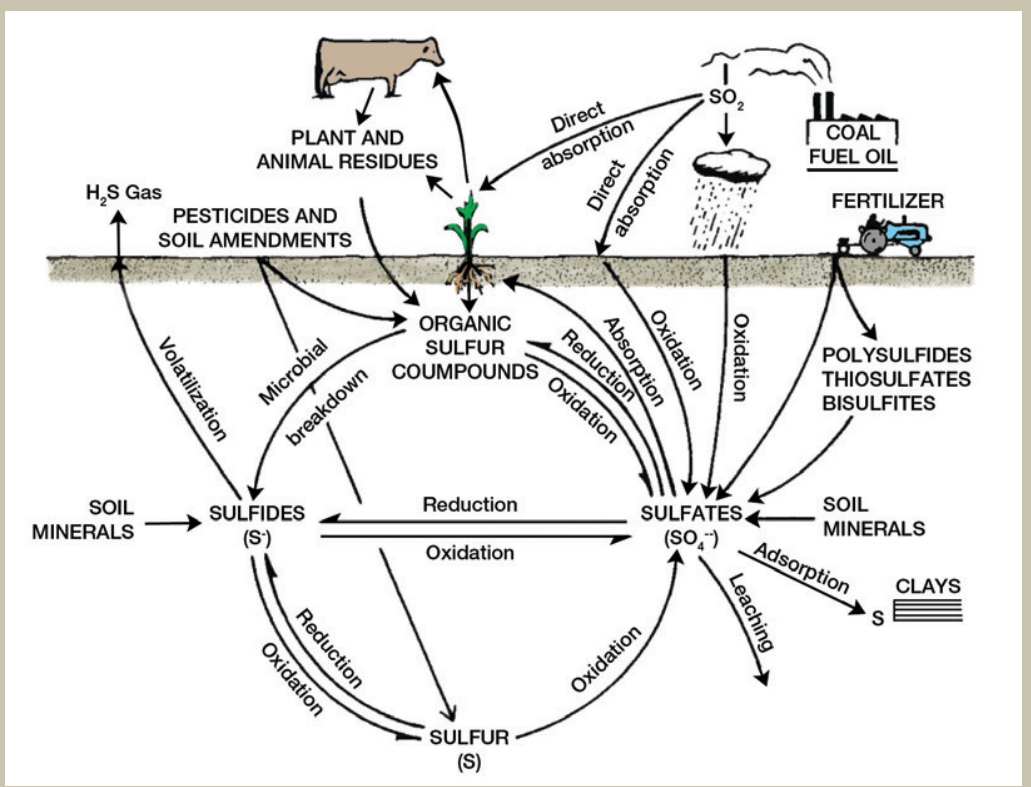

Fig. 7|1. Simplified version of the sulfur cycle in soils. Adapted from Stevenson and Cole (1999). 
between plant uptake and mineralizationimmobilization (Scherer, 2009).

Sulfate ions reach root surfaces via mass flow and diffusion. In soils with more than $5 \mathrm{mg} \mathrm{L} \mathrm{m}^{-1}$ soluble sulfate, essentially all S required by the crop is supplied by mass flow via the transpiration stream (Barber, 1995). Sulfate concentrations in soil solution are usually lowest in the winter and early spring because of leaching and slow mineralization rates (Castellano and Dick, 1990).

Adsorbed sulfate is in equilibrium with sulfate in soil solution. Adsorption is $\mathrm{pH}$ dependent, and increases as $\mathrm{pH}$ decreases, reaching a maximum at $\mathrm{pH} 3$ (Scherer, 2009). At $\mathrm{pH}$ levels greater than 6.5, adsorption is negligible, and the majority of soil sulfate is found in solution (Curtin and Syers, 1990). In acid soils, sulfate is often adsorbed on the surfaces of hydrous oxides of Fe and $\mathrm{Al}$ and edges of aluminosilicate clay minerals (Bohn et al., 1986). Adsorbed sulfate can significantly contribute to the $S$ needs of plants growing in highly weathered, acidic soils because it is readily available. Sulfate adsorption is influenced by the presence of competing anions, such as phosphate, nitrate, and chloride (Tisdale et al., 1985). Adsorbed sulfate is held less strongly than ortho-phosphate $\left(\mathrm{HPO}_{4}{ }^{2-}\right)$, so application of soluble $P$ fertilizers will increase the availability of sulfate. Addition of lime also increases sulfate availability as a result of the competition of ortho-phosphate and hydroxyls $\left(\mathrm{OH}^{-}\right)$with sulfate for adsorption sites on Fe and Al oxides (Scherer, 2009). Crops can utilize adsorbed sulfate in subsoils, but early season $S$ deficiencies may occur until root development is sufficient. Deep-rooted crops are less likely to experience these early season deficiencies. Adsorption of sulfate can be a useful mechanism for retaining $S$ in soils prone to leaching (Scherer, 2009).

Microbial oxidation of reduced inorganic $S$ forms, such as elemental S, sulfides, and thiosulfates, to sulfates is an important process in soils (Stevenson and Cole, 1999). Microbial oxidation is performed by both autotrophic and heterotrophic microorganisms, such as Thiobacillus, Pseudomonas, and Arthrobacter. Reducing conditions found in flooded and waterlogged soils can result in sulfate conversion to sulfide. Sulfides are oxidized back to sulfates when the soil becomes aerobic again (Scherer, 2009).

\section{Organic Sulfur}

The organic S pool represents $95 \%$ or more of the total $S$ in most noncalcareous surface soils. Organic $S$ is present in plant and animal residues, microbial biomass and metabolites, and humus. Organic S is rendered plant available through the process of mineralization, while immobilization is the process by which sulfate is converted by soil biota into organic forms that cannot be taken up by roots. Hence, the amount of organic S in soil is highly correlated with organic $C$ and total N. Unless S fertilizer is applied or atmospheric deposition is significant, mineralized $S$ is the dominant input to the plant-available sulfate pool during a growing season (Schoenau and Malhi, 2008).

Soil organic $S$ is a heterogeneous mixture of compounds, many with unknown chemical identity (Kertesz and Mirleau, 2004). Two main groups of S-containing compounds have been identified, namely ester sulfates (C-O-S) and carbon-bonded S (C-S), consisting of S-containing proteins and a variety of heterocyclic compounds. Delineation of these two groups is based on laboratory fractionation procedures in which ester sulfate is determined by hydriodic acid (HI) extraction, and C-bonded S is calculated from the difference between total $S$ and ester sulfate (Tabatabai, 1996). McLaren et al. (1985) found that sulfate added to soil is quickly incorporated into the ester sulfate fraction, and that this pool, rather than the C-bonded $S$ fraction, provides the majority of sulfate taken up by plants. Of the total organic $S$ in soils, 30 to $70 \%$ is found in the organic sulfate fraction (Schoenau and Malhi, 2008). With time, ester sulfate $S$ is converted to C-bonded S, indicating that C-bonded S is a more stable component of the soil organic $S$ pool. Hence, the composition of the organic $S$ pool in soil is an important determinant of the S-supplying capacity for crop plants.

Mineralization of ester sulfates in soil is accomplished by several sulfatase enzymes produced by soil microorganisms (Scherer, 2009). Ester sulfates in soil are hydrolyzed to release inorganic sulfate. Low levels of soil sulfate stimulate microbial production and release of sulfatases. Gupta et al. (1988) found that repeated application of S fertilizers resulted in a decline in sulfatase activity. Sulfur mineralization is greater when growing plants are present, presumably because of higher microbial populations in the 
rhizosphere, which increase sulfatase activity. There is some evidence that plant roots can produce and secrete sulfatase enzymes (Knauff et al., 2003), but further research is needed. Mineralization of C-bonded S occurs when soil microbes utilize the various compounds as a $C$ source and release sulfate during the process (Scherer, 2009). However, mineralization of ester sulfates is much faster than that of C-bonded S compounds, so ester sulfates are more important contributors than C-bonded compounds for short-term $S$ cycling.

The majority of organic $S$ in crop residues is in the form of C-bonded S. Decomposition of residues results in conversion of these compounds into microbial biomass and humic products rich in organic sulfates. Microbial biomass $S$ constitutes less than 3\% of total soil S, but it is quite labile and considered a main factor controlling $S$ turnover in soil (Yang et al., 2007). Greater amounts of biomass $S$ often translate to greater amounts of $S$ available for the crop. Factors controlling microbial activity and the release of plant-available $S$ via mineralization include the $\mathrm{C} / \mathrm{S}$ ratio in the residue being decomposed and environmental conditions (Pirela and Tabatabai, 1988). When the $C / S$ ratio of organic residues is below 200, there is a net release of inorganic sulfate, while at C/S ratios greater than 400 , there is a net loss of inorganic sulfate from the soil (Scherer, 2009). For C/S ratios between 200 and 400, sulfate can be either tied up or released from soil organic matter. Sulfur mineralization rates are greatest when soil water content is greater than $60 \%$ of field capacity and soil temperatures are in the range of 20 to $40^{\circ} \mathrm{C}$ (Stevenson and Cole, 1999). Under optimum soil temperature and moisture conditions, Tabatabai and Bremner (1972) showed that a significant amount of sulfate $S$ will be mineralized in a short period of time.

\section{Spatial (Landscape Scale) and Temporal Variability of Soil Sulfur} Sulfur availability is often associated with landscape position. As S distribution varies across a field, crop response to $S$ fertilizer is also often strongly related to landscape position. Differential yield responses to landscape position have been documented (Haneklaus et al., 2006). Lower landscape positions tend to have higher soil $S$ than upper landscape positions (Roberts and Bettany, 1985). Part of the difference between upper- and lower-slope positions is due to decreased organic matter and associated organic $S$ in soils of the upper landscape surfaces. Higher water tables in lower landscapes result in higher subsoil sulfate (Haneklaus et al., 2008). Sulfur deficiencies are most often observed on hilltop and side-slope positions, especially on eroded, coarse-textured soils. However, an exception can occur where gypsum occurs near the surface on eroded knolls, provided that there is readily available sulfate for early growth of the crop. Sulfur deficiency is less common on foot-slope and toe-slope positions with medium- to heavy-textured soils high in organic matter. It is not unusual to find extremely high soil S concentrations and $S$ deficiencies in the same field. The high variability in $S$ concentration within a field poses challenges for soil testing (Bloem et al., 2001). If soil samples are composited, a sample with excessive $S$ can elevate the results of the soil test and may lead to the conclusion that the field is well-supplied with $S$, when in fact the majority of the field is $S$ deficient.

\section{Assessing the Need for Sulfur}

As the need to supplement $S$ to achieve optimum crop production grows, greater attention will need to be paid to diagnostic tests that accurately predict responses. These tests must be reproducible and come at a reasonable cost. At present, soil tests that aim to extract some fraction of inorganic $S$ and/or mineralizable organic $S$, and plant diagnostic tests that measure what the plant has captured at a specific stage of growth are available. Blanchar (1986), Jones (1986), Tabatabai (1996), and Dick et al. (2008) provide excellent reviews of testing methodology.

\section{Soil Testing and Availability Indices}

Although offered by many public and commercial laboratories, soil testing has not generally been very effective for predicting crop responses to available soil S (Dick et al., 2008). This is in part because a soil test cannot provide an estimate of the amount 
of atmospheric $S$ that continuously supplies a crop with $S$. These atmospheric inputs vary with the time of year, amount of rainfall, and location of the field in relation to $S$ sources. In general, the significant spatial and temporal variability in sulfate distribution creates problems in soil testing and subsequent recommendations for $S$ fertilizers. Nevertheless, soil tests have been widely used for many years to predict crop requirements for $S$. Various extractants have been used, including water, acetates, carbonates, chlorides, phosphates, citrates, and oxalates (Jones, 1986; Kowalenko and Grimmett, 2008). The monocalcium phosphate or potassium phosphate extractant is commonly used in North America to predict S availability. There are many shortcomings to the procedure, which were identified early in its use (Hoeft et al., 1973). Blair et al. (1991) developed a method utilizing warm $\left(40^{\circ} \mathrm{C}\right)$ potassium chloride solution for Australian soils, but this test has limited use elsewhere. Schoenau et al. (1993) reported good correlations between soil S measured with anion exchange resin membranes and plant $S$ availability, but the method also has seen limited use.

The lack of a good correlation between soil tests and crop response has led to the consideration of N/S ratios in soils as an indication of sulfur supply (Janzen and Bettany, 1984). Total sulfur in a selected group of Canadian soils was highly correlated with organic carbon and total nitrogen (Bailey, 1985). It was suggested that soils with a high N/S ratio could be prone to sulfur deficiency.

\section{Plant Analysis}

Plant-tissue testing for $S$ can also be used as an indication of $S$ status of the crop (Jones, 1986; Mills and Jones, 1996). The plant growth stage and the plant part sampled are the most important variables to consider when using plant tissue testing to diagnose potential S problems. However, excess S can be taken up and stored as sulfate in the plant, which makes a plant diagnostic test more difficult. Although few studies have documented direct interaction of $\mathrm{N}$ and $\mathrm{S}$ fertility, plant N/S ratio has also been suggested as an indication of sulfur deficiency (Marschner, 1995). Bailey (1986) suggested that for maximum yield in Canadian soils, canola should have a total N/S ratio of 12 in the tissue at flowering, while barley (Hordeum vulgare L.) requires a ratio of 16 in the tissue at flag-leaf. Zhao et al. (1997), however, reported that sulfur-deficient rapeseed and that with sufficient $S$ had similar N/S ratios. One of the problems with relying on plant analysis to diagnose sulfur problems is that if the problem is found, application of sulfur may come too late to benefit the crop during that growing season (Malhi et al., 2005).

\section{Managing Sulfur Amendments}

With a goal of maintaining or increasing crop production, any deficits in the $S$ balance of the system are usually solved by the application of some form of $S$ fertilizer. A wide range of inorganic and organic $S$ fertilizers is available, several of which are listed in Table 7/3. Commercial S fertilizers tend to be inorganic materials that are directly manufactured or are produced as byproducts of other manufacturing processes. Animal manures, municipal biosolids, and composts are common soil amendments that often contain significant organic S. Detailed reviews of individual $\mathrm{S}$ fertilizer products, including their advantages and disadvantages in cropping systems, are available from various sources (Tisdale et al., 1985; Hagstrom, 1986; Boswell and Gregg, 1998; Scherer, 2001).

\section{Inorganic Sulfur Sources}

Sulfur-containing inorganic fertilizers can be divided into two main classes based on $\mathrm{S}$ form. Sulfate materials, such as ammonium sulfate $\left[\left(\mathrm{NH}_{4}\right)_{2} \mathrm{SO}_{4}\right]$ and gypsum $\left(\mathrm{CaSO}_{4}\right)$, provide an immediate source of $\mathrm{S}$ the crop, but the sulfate can be highly susceptible to leaching (Curtin and Syers, 1990). For this reason, sulfate fertilizers should be managed similar to nitrate- $\mathrm{N}$ fertilizers. Elemental $S$ materials provide a more gradual release of sulfate into soil because the $\mathrm{S}$ must first be oxidized to the sulfate form. This reduces the risk of leaching losses, but $\mathrm{S}$ availability to the crop is delayed and crop growth may not be improved (Janzen and Ellert, 1998). More importantly, oxidation of elemental $S$ and other reduced fertilizer $S$ forms produces acidity in the form of 
Table $7 \mid 3$. Examples of common inorganic and organic sulfur fertilizer sources. Adapted from Tisdale et al. (1985) and Dick et al. (2008).

\begin{tabular}{lll} 
& \multicolumn{2}{l}{$\begin{array}{l}\text { Nutrient } \\
\text { concentrations }\end{array}$} \\
& N-P-K & \\
\cline { 2 - 2 } Inorganic sources & & \\
Elemental S & $0-0-0$ & $88-98$ \\
Gypsum (calcium sulfate) & $0-0-0$ & 18 \\
Ammonium sulfate & $21-0-0$ & 24 \\
Ammonium thiosulfate & $12-0-0$ & 26 \\
Magnesium sulfate & $0-0-0$ & 14 \\
Potassium magnesium sulfate & $0-0-18.2$ & 22 \\
Potassium sulfate & $0-0-41.5$ & 18 \\
Aluminum sulfate & $0-0-0$ & 14 \\
Ordinary superphosphate & $0-9-0$ & $11-12$ \\
Organic sources & & \\
Municipal biosolids & $-\dagger$ & $0.3-1.2$ \\
Cattle manure (liquid/solid) & - & $0.15-0.8$ \\
Poultry litter & - & 0.5 \\
Sheep manure & - & 0.35 \\
Swine manure (liquid) & - & 0.25 \\
Composted biosolids & - & 0.44 \\
Composted dairy manure & - & 0.22 \\
Composted crop residues & - & $0.10-0.22$
\end{tabular}

† Nitrogen, phosphorus, and potassium levels in organic sources vary widely, so only typical sulfur concentrations for these materials are given.

sulfuric acid $\left(\mathrm{H}_{2} \mathrm{SO}_{4}\right)$ as shown by following equation:

$$
2 \mathrm{~S}^{0}+3 \mathrm{O}_{2}+2 \mathrm{H}_{2} \mathrm{O} \rightarrow 2 \mathrm{H}_{2} \mathrm{SO}_{4}
$$

In calcareous soils with high $\mathrm{pH}$, this effect can be beneficial by improving the availability of phosphorus and most micronutrients. In some soils, however, soil acidification reduces populations of beneficial bacteria and fungi, which may affect cycling of $S$ and other nutrients (Gupta et al., 1988).

Sulfate fertilizers can be further divided into sulfate and thiosulfate $\left(\mathrm{S}_{2} \mathrm{O}_{3}{ }^{2-}\right)$ forms. Gypsum is the most abundantly available sulfate material. In addition to being mined, gypsum is recovered from flue gases of coalfired power plants, as well as from several industrial processes, such as production of phosphate fertilizers (Tisdale et al., 1985). Ammonium thiosulfate is the most common thiosulfate fertilizer; the clear liquid is widely used in the fluid industry. It can also be added to irrigation water. Following soil application, thiosulfate fertilizers break down to yield approximately equal parts of sulfate and elemental S (Hagstrom, 1986). The elemental $S$ must undergo oxidation to sulfate before it can be captured by plant roots.

Elemental $S$ fertilizers are the most S-dense materials (Table 7|3), but can vary greatly with respect to physical characteristics. Finer particle size allows more rapid conversion to sulfate. To avoid both the difficulties of handling finely divided $S$ particles and the potential fire hazard of the dust, molten elemental S can be mixed with bentonite clay to produce a granular material that mixes well with other granular fertilizers on the market (Hagstrom, 1986). After application to soil, the bentonite clay absorbs water and swells, which then causes the granules to fracture and release the $\mathrm{S}$. Because the $\mathrm{S}$ must be oxidized to sulfate, the effectiveness of the fertilizer can be inconsistent due to differences in both the fineness of the elemental S particles and soil properties, mainly aeration and temperature (Chapman, 1989). Particle fracturing and $\mathrm{S}$ dispersal is enhanced by soil wetting and drying cycles (Nuttall et al., 1993).

Research comparing sulfate sources with elemental $S$ formulations indicates that in the initial year of application sulfate sources are more effective (Solberg et al., 2007). Cool, dry soils and the relatively short growing season that occurs in northern climates may restrict the oxidation of elemental S sources. However, research has shown that residual S from elemental S fertilizers will become available with time, thereby increasing yields in subsequent crops (Janzen and Ellert, 1998; Riley et al., 2000; Solberg et al., 2007). Between conversion to plant-available sulfate and $S$ uptake by the crop, $\mathrm{S}$ from elemental $\mathrm{S}$ fertilizer is subject to leaching losses. Grant et al. (2004) found that the residual benefits of elemental $\mathrm{S}$ and ammonium sulfate were similar 3 yr after fertilizer application.

The combination of increasing $\mathrm{S}$ deficiency and strong demand for high analysis fertilizers that contain little or no $\mathrm{S}$ has lead the fertilizer industry to develop new 
S-enhanced products. The S-enhanced materials are generally monoammonium phosphate (MAP) or diammonium phosphate (DAP) with microparticulate elemental $S$ dispersed throughout the granules (Blair, 2009). Another material has one-half of the $S$ in the sulfate form and the other half in the elemental $S$ form that must be oxidized by soil bacteria to become available to plants. Lefroy et al. (1997) found that oxidation rates of elemental $S$ are enhanced when $\mathrm{S}$ and $\mathrm{P}$ are mixed together in soil, possibly due to the $\mathrm{P}$ and $\mathrm{S}$ nutritional requirements of S-oxidizing microorganisms in the soil (Friesen, 1996). Recent research has shown that these new products may increase the agronomic efficiency of added $S$, which makes $S$ inclusion in traditional $P$ fertilizers an attractive option (Blair, 2009; Kovar and Karlen, 2010).

\section{Organic Sulfur Sources}

Sulfur-bearing organic amendments often contain significant amounts of sulfate and can be effective sources of plant-available $S$ through mineralization. Organic $S$ in these amendments, however, can vary considerably and appears to turn over relatively slowly (Eriksen et al., 1995). Tabatabai and Chae (1991) reported that there was a gradual linear increase in mineralized $S$ with time in five soils amended with four types of animal manure, but that in some cases, $S$ mineralization was slower in manureamended soil than in unamended soil. These results and those of other studies (Eriksen et al., 1995) suggest that animal manures are not a good source of $S$ in the short term. The type of feed and length of storage affect the plant availability of the $S$ in the materials. In addition, animal manures, particularly liquid swine effluent, tend to be low in S relative to $\mathrm{N}$, so that supplemental $\mathrm{S}$ fertilizer is needed to meet the needs of many crops (Schoenau and Davis, 2006).

The impact of municipal biosolids and compost applications on the $S$ dynamics in agricultural soils depends on the C/N/S ratio in the material (Tabatabai and Chae, 1991). Sulfur mineralization can be significant in materials with a low $(\ll<200)$ C/S ratio. Application of compost can also stimulate sulfatase activity in soil, as well as increase levels of microbial biomass S (Perucci, 1990). In some soils, $S$ mineralization following biosolids application can be rapid and provide plant-available $S$ within a few days (Tabatabai and Chae, 1991).

\section{Timing, Placement, and Rate}

The timing of $S$ fertilizer applications, how the various forms of $S$ should be applied to soil, and fertilizer rates for specific crops are all management decisions that require careful consideration. The growth and development of cereal grains, oilseed crops, and various legumes are quite different, so the demand for $S$ varies considerably with growth stage. In general, research has shown that a sufficient $S$ supply is needed during the early growth stages of cereal grains to ensure proper tiller development (Haneklaus et al., 2008). In contrast, insufficient $S$ during the early part of the growing season may have little effect on canola yields if adequate $S$ is available during flowering and seed set (Janzen and Bettany, 1984; Malhi and Gill, 2002; Franzen and Grant, 2008). Excellent reviews of $S$ fertilizer management for specific crops are presented in Jez (2008).

The appropriate time of the year for $S$ application also depends on the $S$ form. Sulfate sources, such as ammonium or potassium sulfate, contain readily available $S$ and should be applied at or near the time of planting to reduce $S$ losses. In soils with low organic matter content, sandy texture, or rapid water movement through the profile, fall applications of sulfate materials should be avoided (Hagstrom, 1986). Soil or foliar applications of sulfate sources can also be used to correct $S$ deficiencies during the growing season. To be effective, in-season soil (top-dress) applications depend on rainfall or irrigation to move the $S$ into the root zone, although Kovar and Karlen (2010) found increased sulfate concentrations in the root zone approximately $4 \mathrm{wk}$ after a surface application of liquid ammonium thiosulfate (Fig. 7/2). Elemental S sources must be applied early enough to allow oxidation of $S$ to the sulfate form before the time of crop demand. Solberg et al. (2003) reported that fall application of elemental $S$ allowed fertilizer granules to break down with freezing-thawing and wetting-drying cycles, thus aiding oxidation of elemental S during the growing season. However, Grant et al. (2004) found that even with fall application, conversion of elemental $S$ to sulfate 


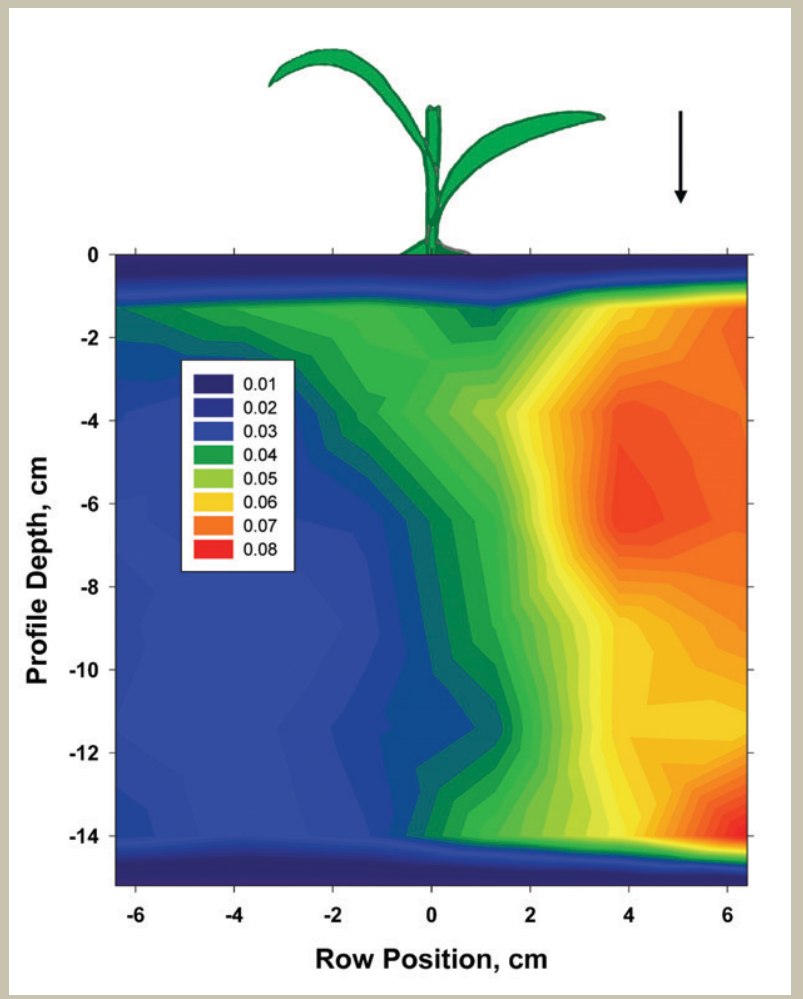

Fig. 7|2. Root zone distribution of bioavailable sulfur $26 \mathrm{~d}$ after application of ammonium thiosulfate (12-0-0-26 S) liquid fertilizer on the soil surface approximately $5 \mathrm{~cm}$ to the side of the maize row (arrow) in 2009 (Kovar and Karlen, 2010). Sulfur concentrations are micrograms sulfate $\left(\mathrm{SO}_{4}{ }^{2-}\right) \mathrm{S} \mathrm{cm}^{-2}$ soil and were determined by extraction with bicarbonate-saturated exchange resin membranes.

may be too slow in the northern Great Plains to optimize yield of a spring crop.

The effectiveness of $S$ fertilizer placement, as with the timing of $S$ application, depends on the type of material applied and the soil to which the fertilizer is applied. Sulfate sources that are broadcast with or without incorporation at or near planting can provide readily available $S$ to the crop (Malhi et al., 2005). In soils with adequate plant-available $S$ in the subsoil, row or band application of sulfate sources at the time of planting can be quite effective (Hagstrom, 1986; Grant and Bailey, 1993). Care must be taken, however, to avoid seedling damage caused by excessive sulfate concentrations in contact with young roots. Elemental S sources generally should not be applied in bands, because this application practice reduces the contact of the $S$ with oxidizing microorganisms in the soil (Nuttall et al., 1993). Broadcast application of elemental S should include tillage to mix the material with soil in the root zone. In flooded rice (Oryza sativa L.) systems, Blair and Lefroy (1998) suggest that S fertilizers should be placed on or near the soil surface to take advantage of the oxidized zone. Deep placement of sulfate sources decreases $S$ availability as a result of reduction of sulfate to sulfide (Samosir et al., 1993).

The amount of $S$ fertilizer needed for efficient production of a particular crop requires the integration of a significant amount of information. Nevertheless, general guidelines have been developed for important crops in specific regions. In the Midwest and northeastern United States, Hoeft and Fox (1986) found that an annual application of $28 \mathrm{~kg} \mathrm{~S} \mathrm{ha}^{-1}$ was adequate for alfalfa production, and $17 \mathrm{~kg} \mathrm{~S} \mathrm{ha}^{-1}$ were adequate for maize. Kamprath and Jones (1986) reported that $S$ fertilization rates required for optimum maize yields in the southeastern United States ranged from 18 to $66 \mathrm{~kg} \mathrm{~S} \mathrm{ha}^{-1}$, with the higher amounts required on deeper, coarse-textured soils. For a soybean crop, 22 $\mathrm{kg} \mathrm{S} \mathrm{ha-1}$ were adequate. When canola or other S-demanding crops are grown in the Great Plains of the United States and Canada, $\mathrm{S}$ fertilizer rates as high as $30 \mathrm{~kg} \mathrm{~S} \mathrm{ha}^{-1}$ or more may be needed, depending on yield potential (Malhi et al., 2005). Blake-Kalff et al. (2000) found that oilseed rape grown in 
the UK requires more than $12 \mathrm{~kg} \mathrm{~S} \mathrm{ha}^{-1}$ for optimum yields, while a wheat crop requires less than $10 \mathrm{~kg} \mathrm{~S} \mathrm{ha-1.} \mathrm{Khurana} \mathrm{et} \mathrm{al.} \mathrm{(2008)}$ suggested that $S$ fertilizer rates be increased for all crops grown in the Indo-Gangetic Plains of southern Asia. Application of 20 $\mathrm{kg} \mathrm{S} \mathrm{ha-1}$ is needed for raya (Brassica juncea L.) and lentil (Lens culinaris L.), while rice responds to applications up to $42 \mathrm{~kg} \mathrm{~S} \mathrm{ha}^{-1}$. Because of the widespread use of urea and $\mathrm{S}$-free $\mathrm{P}$ and $\mathrm{K}$ fertilizers, rice production in Southeast Asia can benefit from S applications up to $60 \mathrm{~kg} \mathrm{~S} \mathrm{ha}^{-1}$ (Blair et al., 1979). The values listed here are broad averages based on reviews of available research. Results from a long-term fertility trial in Sweden (Kirchmann et al., 1996) indicated that when excessive amounts of $S$ fertilizer are applied, leaching losses of $S$ significantly increase. Therefore, $\mathrm{S}$ fertilizer recommendations, as those for other essential nutrients, must be site specific.

\section{Challenges in Managing the Sulfur Fertility of Soils}

Sulfur deficiencies will continue to be a growing problem due to ever-increasing crop yields, less atmospheric S deposition, less $S$ applied as an impurity in fertilizers, and continued erosion of topsoil in which most mineralizable organic $S$ is found. Decreased tillage affects the breakdown rate of residues and changes $S$ release. Bioenergy feedstock production will result in greater $S$ removals per unit of land area (Johnson et al., 2010), and increased drainage of agricultural lands will exacerbate leaching losses of $S$.

Sulfur deficiency not only impairs crop yield and quality, but also impacts environmental quality. Schnug (1991) found that for many European crops, N-use efficiency decreased when $S$ was deficient, which led to significant increases in $\mathrm{N}$ losses through volatilization and leaching. Haneklaus et al. (2008) calculated that each kilogram of $\mathrm{S}$ deficit results in $15 \mathrm{~kg}$ of $\mathrm{N}$ loss to the environment.

Better methods for predicting crop $S$ requirements are needed. Tissue tests provide information on plant capture of $S$ from the soil and air, but are postmortem evaluations. Current soil tests more or less provide a snapshot of plant-available S. However, the balance between inputs and outputs from the available S pool during the growing season can have a significant impact on how much $S$ is actually captured and utilized by the crop. This dynamic must be understood if accurate $S$ fertilizer recommendations are to be made. The $S$ balance of a crop production system on a local or regional scale will determine the external $S$ requirements and the long-term stability of the system. If the $\mathrm{S}$ balance is negative, the system cannot be sustained.

Crop production systems are changing, but research addressing $S$ nutrition lags. Many specialty fertilizers are coming onto the market. The agronomics and environmental impact of these materials are still uncertain. Little research addresses S-use efficiency of newer crop cultivars. Inter- and transdisciplinary efforts are necessary to unravel the interrelationships between $S$ and other essential nutrients, and to understand their metabolic pathways within crop plants (Haneklaus et al., 2008). An understanding of the underlying mechanisms at the gene, cell, and whole-plant levels may allow us to grow crops with improved quality and resistance to stresses (Hawkesford and De Kok, 2006). This knowledge is also required if we hope to develop sophisticated nutrient management systems for future agricultural production.

\section{References}

Alway, F.J. 1940. A nutrient element slighted in agricultural research. J. Am. Soc. Agron. 32:913-921.

Bailey, L.D. 1985. The sulphur status of eastern Canadian prairie soils: The relationship of sulphur, nitrogen and organic carbon. Can. J. Soil Sci. 65:179-185.

Bailey, L.D. 1986. The sulphur status of eastern Canadian prairie soils: Sulphur response and requirements of alfalfa (Medicago sativa L.), rape (Brassica napus L.) and barley (Hordeum vulgare L.). Can. J. Soil Sci. 66:209-216.

Barber, S.A. 1995. Soil nutrient bioavailability-A mechanistic approach. 2nd ed. John Wiley and Sons, New York.

Bennett, W.F. 1993. Nutrient deficiencies and toxicities in crop plants. APS Press. St. Paul, MN.

Blair, G.J. 2009. Sulphur enhanced fertilizer (SEF). A new generation of fertilizers. Proc. Int. Plant Nutr. Colloq. XVI. Available at http://escholarship.org/uc/ item/16h5b2dm (verified 7 Feb. 2011). Univ. of California, Davis.

Blair, G., and R. Lefroy. 1998. Sulfur and carbon research in rice production systems. Field Crops Res. 56:177-181.

Blair, G.J., E.O. Momuat, and C.P. Mamaril. 1979. Sulfur nutrition of rice. II. Effect of source and rate of $S$ on growth and yield under flooded conditions. Agron. J. 71:477-480.

Blair, G.J., N. Chinoim, R.D.B. Lefroy, G.C. Anderson, and G.J. Crocker. 1991. A sulfur soil test for pastures and crops. Aust. J. Soil Res. 29:619-626. 
Blake-Kalff, M.M.A., M.J. Hawkesford, FJ. Zhao, and S.P. McGrath. 2000. Diagnosing sulfur deficiency in field-grown oilseed rape (Brassica napus L.) and wheat (Triticum aestivum L.). Plant Soil 225:95-107.

Blanchar, R.W. 1986. Measurement of sulfur in soils and plants. p. 455-490. In M.A. Tabatabai (ed.) Sulfur in agriculture. Agron. Monogr. 27. ASA, CSSA, and SSSA, Madison, WI.

Bloem, E., S. Haneklaus, G. Sparovek, and E. Schnug. 2001. Spatial and temporal variability of sulphate concentration in soils. Commun. Soil Sci. Plant Anal. 32:1391-1403.

Bohn, H.L., N.J. Barrow, S.S.S. Rajan, and R.L. Parfitt. 1986. Reactions of inorganic sulfur in soils. p. 233-249. In M.A. Tabatabai (ed.) Sulfur in agriculture. Agron. Monogr. 27. ASA, CSSA, and SSSA, Madison, WI.

Boswell, C.C., and P.E.H. Gregg. 1998. Sulfur fertilizers for grazed pasture systems. p. 95-134. In D.G. Maynard (ed.) Sulfur in the environment. Marcel Dekker, New York.

Boyhan, G.E. 2008. Sulfur, its role in onion production and related alliums. p. 183-196. In J. Jez (ed.) Sulfur: A missing link between soils, crops, and nutrition. Agron. Monogr. 50. ASA, CSSA, and SSSA, Madison, WI.

Castellano, S.D., and R.P. Dick. 1990. Cropping and sulfur fertilization influence on sulfur transformations in soils. Soil Sci. Soc. Am. J. 54:114-121.

Chapman, S.J. 1989. Oxidation of micronized elemental sulphur in soil. Plant Soil 116:69-76.

Curtin, D., and J.K. Syers. 1990. Extractability and adsorption of sulphate in soils. J. Soil Sci. 41:295-304.

Dick, W.A., D. Kost, and L. Chen. 2008. Availability of sulfur to crops from soil and other sources. p. 59-82. In J. Jez (ed.) Sulfur: A missing link between soils, crops, and nutrition. Agron. Monogr. 50. ASA, CSSA, and SSSA, Madison, WI.

Droux, M. 2004. Sulfur assimilation and the role of sulfur in plant metabolism: A survey. Photosynth. Res. 79:331-348.

Duke, S.H., and H.M. Reisenauer. 1986. Roles and requirements of sulfur in plant nutrition. p. 123-168. In M.A. Tabatabai (ed.) Sulfur in agriculture. Agron. Monogr. 27. ASA, CSSA, and SSSA, Madison, WI.

Eriksen, J., J.V. Mortensen, V.K. Kjellerup, and O. Kristjansen. 1995. Forms and plant-availability of sulfur in cattle and pig slurry. Z. Pflanzenernaehr. Bodenkd. 158:113-116.

Franzen, D., and C.A. Grant. 2008. Sulfur response based on crop, source, and landscape position. p. 105-116. In J. Jez (ed.) Sulfur: A missing link between soils, crops, and nutrition. Agron. Monogr. 50. ASA, CSSA, and SSSA, Madison, WI.

Friesen, D.K. 1996. Influence of co-granulated nutrients and granule size on plant responses to elemental sulfur in compound fertilizers. Nutr. Cycling Agroecosyst. 46:81-90.

Grant, C.A., and L.D. Bailey. 1993. Fertility management in canola production. Can. J. Plant Sci. 73:651-670.

Grant, C.A., A.M. Johnston, and G.W. Clayton. 2004. Sulphur fertilizer and tillage management of canola and wheat in western Canada. Can. J. Plant Sci. 84:453-462.

Gregory, P.J., D.V. Crawford, and M. McGowan. 1979 Nutrient relations of winter wheat: 1 . Accumulation and distribution of $\mathrm{Na}, \mathrm{K}, \mathrm{Ca}, \mathrm{Mg}, \mathrm{P}, \mathrm{S}$ and N. J. Agric. Sci. 93:485-494.

Gupta, V.V.S.R., J.R. Lawrence, and J.J. Germida. 1988. Impact of elemental sulfur fertilization on agricultural soils. I. Effects on microbial biomass and enzyme activities. Can. J. Soil Sci. 68:463-473.

Hagstrom, G.R. 1986. Fertilizer sources of sulfur and their use. p. 567-581. In M.A. Tabatabai (ed.) Sulfur in agriculture. Agron. Monogr. 27. ASA, CSSA, and SSSA, Madison, WI.

Haneklaus, S., E. Bloem, and E. Schnug. 2006. Sulphur interactions in crop ecosystems. p. 17-58. In M.J.
Hawkesford and L.J. De Kok (ed.) Sulfur in plantsAn ecological perspective. Springer, Dordrecht, The Netherlands.

Haneklaus, S., E. Bloem, and E. Schnug. 2008. History of sulfur deficiency in crops. p. 45-58. In J. Jez (ed.) Sulfur: A missing link between soils, crops, and nutrition. Agron. Monogr. 50. ASA, CSSA, and SSSA, Madison, WI.

Haneklaus, S., E. Evans, and E. Schnug. 1992. Baking quality and sulphur content of wheat: II: Evaluation of the relative importance of genetics and environment including sulphur fertilization. Sulphur Agric. 16:35-38.

Hawkesford, M.J., and L.J. De Kok. 2006. Managing sulphur metabolism in plants. Plant Cell Environ. 29:382-395.

Hoeft, R.G., and R.H. Fox. 1986. Plant response to sulfur in the Midwest and northeastern United States. p. 345-356. In M.A. Tabatabai (ed.) Sulfur in agriculture. Agron. Monogr. 27. ASA, CSSA, and SSSA, Madison, WI.

Hoeft, R.G., L.M. Walsh, and D.R. Keeney. 1973. Evaluation of various extractants for available soil sulfur. Soil Sci. Soc. Am. Proc. 37:401-404.

Janzen, H.H., and J.R. Bettany. 1984. Sulfur nutrition of rapeseed. II. Effect of time of sulfur application. Soil Sci. Soc. Am. J. 48:107-112.

Janzen, H.H., and B.H. Ellert. 1998. Sulfur dynamics in cultivated, temperate agroecosystems. p. 11-44. In D.G. Maynard (ed.) Sulfur in the environment. Marcel Dekker, New York.

Jez, J. (ed.). 2008. Sulfur: A missing link between soils, crops, and nutrition. Agron. Monogr. 50. ASA, CSSA, and SSSA, Madison, WI.

Johnson, J.M., W.W. Wilhelm, D.L. Karlen, D.W. Archer, B.J. Wienhold, D.T. Lightle, D.A. Laird, J.M. Baker, T.E. Ochsner, J.M. Novak, A.D. Halvorson, F.J. Arriaga, and N.W. Barbour. 2010. Nutrient removal as a function of corn stover cutting height and cob harvest. BioEnergy Res. 3:342-352.

Jones, M.B. 1986. Sulfur availability indexes. p. 549-566. In M.A. Tabatabai (ed.) Sulfur in agriculture. Agron. Monogr. 27. ASA, CSSA, and SSSA, Madison, WI.

Kamprath, E.J., and U.S. Jones. 1986. Plant response to sulfur in the southeastern United States. p. 323-343. In M.A. Tabatabai (ed.) Sulfur in agriculture. Agron. Monogr. 27. ASA, CSSA, and SSSA, Madison, WI.

Kertesz, M.A., and P. Mirleau. 2004. The role of soil microbes in plant sulphur nutrition. J. Exp. Bot. 55:1939-1945.

Khurana, M.P.S., U.S. Sadana, and Bijay-Singh. 2008. Sulfur nutrition of crops in the Indo-Gangetic Plains of south Asia. p. 11-24. In J. Jez (ed.) Sulfur: A missing link between soils, crops, and nutrition. Agron. Monogr. 50. ASA, CSSA, and SSSA, Madison, WI.

Kirchmann, H., F. Pichlmayer, and M.H. Gerzabek. 1996. Sulfur balances and Sulfur-34 abundance in a long-term fertilizer experiment. Soil Sci. Soc. Am. J. 60:174-178.

Knauff, U., M. Schulz, and H.W. Scherer. 2003. Arylsulfatase activity in the rhizosphere and roots of different crop species. Eur. J. Agron. 19:215-223.

Kovar, J.L., and D.L. Karlen. 2010. Is sulfur limiting maize grown on eroded Midwestern U.S. soils? In R.J. Gilkes and N. Prakongkep (ed.) Proc. 19th World Congress Soil Sci., 1-6 Aug. 2010, Brisbane, Australia. [DVD.] IUSS, Brisbane, Australia.

Kowalenko, C.G., and M. Grimmett. 2008. Chemical characterization of soil sulfur. p. 251-263. In M.R. Carter and E.G. Gregorich (ed.) Soil sampling and methods of analysis. 2nd ed. CRC Press, Boca Raton, FL.

Krishnan, H.B. 2008. Improving the sulfur-containing amino acids of soybean to enhance its nutritional value in animal feed. p. 235-249. In J. Jez (ed.) Sulfur: A missing link between soils, crops, and nutrition. Agron. Monogr. 50. ASA, CSSA, and SSSA, Madison, WI. 
Lefroy, R.D.B., Sholeh, and G. Blair. 1997. Influence of sulfur and phosphorus placement, and sulfur particle size, on elemental sulfur oxidation and the growth response of maize (Zea mays). Aust. J. Agric. Res. 48:485-495.

Malhi, S.S., and K.S. Gill. 2002. Effectiveness of sulphate$S$ fertilization at different growth stages for yield, seed quality and S uptake of canola. Can. J. Plant Sci. 82:665-674.

Malhi, S.S., J.J. Schoenau, and C.A. Grant. 2005. A review of sulphur fertilizer management for optimum yield and quality of canola in the Canadian Great Plains. Can. J. Plant Sci. 85:297-307.

Marschner, H. 1995. Mineral nutrition of higher plants. 2nd ed. Academic Press, London.

McGrath, S.P., and F.J. Zhao. 1995. A risk assessment of sulphur deficiency in cereals using soil and atmospheric deposition data. Soil Use Manage. 11:110-114.

McLaren, R.G., J.I. Keer, and R.S. Swift. 1985. Sulphur transformations in soils using sulphur-35 labelling. Soil Biol. Biochem. 17:73-79.

Mills, H.A., and J.B. Jones, Jr. 1996. Plant analysis handbook II. MicroMacro Publishing, Inc., Athens, GA.

Nuttall, W.F., C.C. Boswell, A.G. Sinclair, A.P. Moulin, L.J. Townley-Smith, and G.L. Galloway. 1993. The effect of time of application and placement of sulphur fertilizer sources on yield of wheat, canola, and barley. Commun. Soil Sci. Plant Anal. 24:2193-2202.

Pavlista, A.D. 2005. Early-season applications of sulfur fertilizers increase potato yield and reduce tuber defects. Agron. J. 97:599-603.

Perucci, P. 1990. Effect of the addition of municipal solidwaste compost on microbial biomass and enzyme activities in soil. Biol. Fertil. Soils 10:221-226.

Pirela, H.J., and M.A. Tabatabai. 1988. Sulphur mineralization rates and potentials of soils. Biol. Fertil. Soils 6:26-32.

Riley, N.G., F.J. Zhao, and S.P. McGrath. 2000. Availability of different forms of sulphur fertilizers to wheat and oilseed rape. Plant Soil 222:139-147.

Roberts, T.L., and J.R. Bettany. 1985. The influence of topography on the nature and distribution of soil sulfur across a narrow environmental gradient. Can. J. Soil Sci. 65:419-434.

Samosir, S.S.R., G.J. Blair, and R.D.B. Lefroy. 1993. Effects of placement of elemental $S$ and sulfate on the growth of two rice varieties under flooded conditions. Aust. J. Agric. Res. 44:1775-1788.

Scherer, H.W. 2001. Sulphur in crop production-Invited paper. Eur. J. Agron. 14:81-111.

Scherer, H.W. 2009. Sulfur in soils. J. Plant Nutr. Soil Sci. 172:326-335.

Schnug, E. 1991. Sulphur nutritional status of European crops and consequences for agriculture. Sulphur Agric. 15:7-12.

Schoenau, J.J., and J.G. Davis. 2006. Optimizing soil and plant responses to land-applied manure nutrients in the Great Plains of North America. Can. J. Soil Sci. 86:587-595.

Schoenau, J.J., and S.S. Malhi. 2008. Sulfur forms and cycling processes in soil and their relationship to soil fertility. p. 1-10. In J. Jez (ed.) Sulfur: A missing link between soils, crops, and nutrition. Agron. Monogr. 50. ASA, CSSA, and SSSA, Madison, WI.
Schoenau, J.J., P. Qian, and W.Z. Huang. 1993. Assessing sulphur availability in soil using ion exchange resins. Sulphur Agric. 17:13-17.

Solberg, E.D., S.S. Malhi, M. Nyborg, and K.S. Gill. 2003. Fertilizer type, tillage, and application time effects on recovery of sulfate-S from elemental sulfur fertilizers in fallow field soils. Commun. Soil Sci. Plant Anal. 34:815-830.

Solberg, E.D., S.S. Malhi, M. Nyborg, B. Henriquez, and K.S. Gill. 2007. Crop response to elemental S and sulfate-S sources on S-deficient soils in the Parkland Region of Alberta and Saskatchewan. J. Plant Nutr. 30:321-333.

Spencer, K. 1975. Sulphur requirements of plants. p. 98-108. In K.D. McLachlan (ed.) Sulphur in Australasian agriculture. Sydney Univ. Press, Sydney.

Stevenson, F.J., and M.A. Cole. 1999. Cycles of soil-Carbon, nitrogen, phosphorus, sulfur, micronutrients. 2nd ed. John Wiley and Sons, New York.

Stuiver, C.E.E., and L.J. De Kok. 2001. Atmospheric $\mathrm{H}_{2} \mathrm{~S}$ as sulfur source for Brassica oleracea: Kinetics of $\mathrm{H}_{2} \mathrm{~S}$ uptake and activity of $\mathrm{O}$-acetylserine (thiol)lyase as affected by sulfur nutrition. Environ. Exp. Bot. 46:29-36

Tabatabai, M.A. (ed.) 1986. Sulfur in agriculture. Agron. Monogr. 27. ASA, CSSA, and SSSA, Madison, WI.

Tabatabai, M.A. 1996. Sulfur. p. 921-960. In D.L. Sparks (ed.) Methods of soil analysis. Part 3. Chemical methods. SSSA Book Series No. 5. ASA, CSSA, and SSSA Madison, WI.

Tabatabai, M.A., and J.M. Bremner. 1972. Forms of sulfur, and carbon, nitrogen and sulfur relationships, in Iowa soils. Soil Sci. 114:380-386.

Tabatabai, M.A, and Y.M. Chae. 1991. Mineralization of sulfur in soils amended with organic wastes. J. Environ. Qual. 20:684-690.

Tisdale, S.L., W.L. Nelson, and J.D. Beaton. 1985. Soil fertility and fertilizers. 4th ed. Macmillan Publishing Co., New York.

Tisdale, S.L. R.B. Reneau, Jr., and J.S. Platou. 1986. Atlas of sulfur deficiencies. p. 295-322. In M.A. Tabatabai (ed.) Sulfur in agriculture. Agron. Monogr. 27. ASA, CSSA, and SSSA, Madison, WI.

Westerman, R.L. 1990. Soil testing and plant analysis. 3rd ed. SSSA Book Ser. 3. ASA, CSSA, and SSSA, Madison, WI.

Westerman, S., L.J. De Kok, C.E.E. Stuiver, and I. Stulen. 2000. Interaction between metabolism of atmospheric $\mathrm{H}_{2} \mathrm{~S}$ in the shoot and sulfate uptake by the roots of curly kale (Brassica oleracea). Physiol. Plant. 109:443-449.

Yang, Z., B.R. Singh, S. Hansen, Z. Hu, and H. Riley. 2007. Aggregate associated sulfur fractions in longterm (>80 years) fertilized soils. Soil Sci. Soc. Am. J. 71:163-170.

Zhao, F.J., P.E. Bilsborrow, E.J. Evans, and S.P. McGrath. 1997. Nitrogen to sulphur ratio in rapeseed and in rapeseed protein and its use in diagnosing sulphur deficiency. J. Plant Nutr. 20:549-558.

Zhao, F.J., M.J. Hawkesford, and S.P. McGrath. 1999. Sulphur assimilation and effects on yield and quality of wheat. J. Cereal Sci. 30:1-17. 
